\title{
Austrolimnius cleidecostae, a new species of riffle beetle (Coleoptera: Elmidae) from Brazil with habitat notes and updated key of the Brazilian species of the genus
}

\author{
Thiago Tadeu Silva Polizei ${ }^{14}$; Lucas de Souza Machado Costa ${ }^{2,3,5}$ \& Pitágoras da Conceição Bispo ${ }^{2,6}$ \\ ${ }^{1}$ Universidade de São Paulo (USP), Museu de Zoologia (MZUSP). São Paulo, SP, Brasil. \\ 2 Universidade Estadual Paulista (UNESP), Faculdade de Ciências e Letras, Departamento de Ciências Biológicas, \\ Laboratório de Biologia Aquática. Assis, SP, Brasil. \\ ${ }^{3}$ Universidade de São Paulo (USP), Faculdade de Filosofia, Ciências e Letras de Ribeirão Preto (FFCLRP), \\ Departamento de Biologia, Programa de Pós-Graduação em Entomologia. Ribeirão Preto, SP, Brasil. \\ ${ }^{4}$ ORCID: http://orcid.org/0000-0003-3746-8865. E-mail: thiagopolizei@hotmail.com \\ ${ }^{5}$ ORCID: http://orcid.org/0000-0002-7104-4508. E-mail: lucassmcosta@yahoo.com.br \\ ${ }^{6}$ ORCID: http://orcid.org/0000-0002-7356-8882. E-mail: pcbispo@gmail.com
}

\begin{abstract}
Austrolimnius cleidecostae sp. nov. is one of the smallest species of Elmidae from the Neotropical region. The new species is described and illustrated based on male and female specimens. This species represents the first record in Elmidae of mandibles with an articulated, sclerotized process on inner subapical edge. The specimens were collected from streams in the Atlantic rainforest of São Paulo and Santa Catarina, and habitat notes are given. An updated key for the Austrolimnius Carter \& Zeck, 1929 of Brazil is provided. Austrolimnis browni Hinton, 1971 and A. musgravei Hinton, 1939 are recorded for the first time from Brazil.
\end{abstract}

Key-Words. Aquatic beetles; Streams; Neotropical; South America; Taxonomy.

\section{INTRODUCTION}

The cosmopolitan family Elmidae (riffle beetle) is one of the world's most diverse families of aquatic beetles, with approximately 1,500 species in 153 genera. Austrolimnius Carter \& Zeck, 1929 is the second richest genus of the family, with 104 species and two subspecies, occurring in the Australasian and Neotropical regions (Jäch et al., 2016a). About $2 / 3$ 's of all described species of this genus occur in Australia and Papua New Guinea. Twenty-one species are in the Neotropical region, seven of which are recorded from Brazil (Jäch et al., 2016a).

Austrolimnius species are easily differentiated from those of any other elmid genus by the presence of one or two rows of granules on each epipleuron (Hinton, 1965). Another diagnostic character is the small size, with specimens rarely larger than $2 \mathrm{~mm}$ length. In this paper, the male and female of a new species of Austrolimnius from Brazilian rainforest (São Paulo and Santa Catarina states) are described and illustrated. In addition, we present habitat notes, distributional data, new records and an updated key for the Austrolimnius species from Brazil.

\section{MATERIAL AND METHODS}

The specimens were collected in a joint expedition to preserved streams from Atlantic rainforest in São Paulo state (July 2012, 2013) and Santa Catarina state (September and October 2016). The material studied was preserved in alcohol $80 \%$ and $96 \%$. Specimens deposited in museums were also studied. The species of Austrolimnius were identified using the taxonomic key of Miranda et al. (2012), the original descriptions, and comparison to photographs of holotypes deposited in the Natural History Museum (BMNH, London, United Kingdom) and the Muséum national d'Histoire naturelle (MNHN, Paris, France).

The general morphological terminology follows Kodada et al. (2016). For dissection, mouthparts, abdominal sternites and male genitalia were detached from the specimens and cleared in heated $10 \% \mathrm{KOH}$ for five minutes (Brown, 1972). 
These structures were observed, drawn and then stored on slides using glycerine jelly.

The morphological study was done using a Leica WILD M10 stereoscopic microscope. Photographs of the mandibles were taken using a Zeiss Axioskop microscope attached to a camera. Photographs of the adults were taken using a Canon EOS Rebel T3i DSLR camera + Canon MP-E 65 mm f/2.8 1-5× macro lens, controlled by Zerene Stacker software. Measurements in millimetres were taken using an Hensoldt/Wetzlar - Mess 10 ocular micrometrics in a Leica M10 stereomicroscope. Photographs were taken from dry specimens. Trace illustrations were made using a ZEISS Axioskop microscope equipped with a camera lucida. Photographs and drawings were edited using Adobe Photoshop CC ${ }^{\circledR}$ and Adobe Illustrator CC ${ }^{\circledR}$.

Type specimen's labels are quoted verbatim. A change of lines is indicated by "/" and different labels are indicated by "//". The specimens from São Paulo were collected in alcohol $80 \%$ then pinned. The specimens from Santa Catarina were collected and preserved in $96 \%$ alcohol and retained in a DNA-grade collection at MZSP.

The holotype and paratypes of $A$. cleidecostae sp. nov. are deposited in the following collections (curator in parentheses).

MZSP: Museu de Zoologia da Universidade de São Paulo - São Paulo, Brazil (Sônia Casari).

USNM: Natural History Museum of Smithsonian Institution, Washington, DC, USA (Terry Erwin).

BMNH: Natural History Museum, London, United Kingdom (Maxwell Barclay).

\section{RESULTS}

\section{Austrolimnius cleidecostae sp. nov.} (Figs. 1-24)

Type Material: Holotype male (MZSP):"ox // Holo- / type //BRASIL. São Paulo. São Miguel / Arcanjo. Parque Estadual Carlos / Botelho. 795 m asl. 16.VII.2013 / 2408'30,0"S 4759'41,8'W / Polizei, T.T.S. \& Costa, L.S.M. leg. // MZSP 31185 // (MZSP)". Paratypes (20 specimens): same locality data as holotype (10", 1\%, MZSP 31186-31187; $10^{\prime \prime}$, 19, USNM; 10", 19, BMNH). "BRASIL. São Paulo. Cunha / Parque Estadual Serra do Mar / 988 m asl. 2316'28,4"S 4502'01,6"W / 25.VII.2012 Polizei \& Costa leg." (10', 2ㅇ, MZSP 31188-31190; 19, BMNH). "BRASIL. Santa Catarina. Rancho / Queimado. Riacho das Antas. / $791 \mathrm{~m}$ asl. $27^{\circ} 41^{\prime} 35,0^{\prime \prime} \mathrm{S} 49^{\circ} 00^{\prime} 38,0^{\prime \prime} \mathrm{W} / 01 . X .2016$. Polizei, T.T.S. leg." (40", 3ㅇ, MZSP 31194-31196, 31252-31255), [in alcohol 96\%]. "BRASIL. Santa Catarina. São / Bonifácio. Riacho Dona Bebê. / $470 \mathrm{~m}$ asl. 2754'32,0"S 4854'47,8"W / 29.IX.2016. Polizei, T.T.S. leg." (20', 1, MZSP 31191-31193) [in alcohol 96\%].

Diagnosis: Body subparallel; cuticle alutaceous; general colour dark-brown, with light-yellow antennae, mouthparts, legs and abdominal ventrite V. Mandibles with an articulated sclerotized process on inner subapical edge.
Pronotum with surface alutaceous and without setae, inconspicuously micropunctated, and with longitudinal median impression on basal $2 / 3$ of disc. Epipleura covered by tomentum, each one with two rows of granules. Mesotarsus with a pair of long and thin setae on each tarsomere. Aedeagus with phallobase approximately $3 x$ as long as wide; parameres reaching $4 / 5$ of penis length, with apex rounded with tuft of long setae and rows of micro punctures; penis slightly narrowed at apex with sensorial pores; basolateral apophyses with two lobes; fibula absent; corona present, subquadrate. Female genitalia with valvifer membranous, curved and convergent at base; coxites narrowed apicad; styli slightly curved and with base divergent, apical portion rounded and micropunctated.

Description: Male: Body subparallel; cuticle alutaceous; general colour dark-brown, antennae, mouthparts, legs and ventrite $V$ light-yellow. Body size range $(n=5)$ : total length 1.18-1.20 mm; greatest width 0.45-0.50 mm.

Head: Partially retracted; without impressions, surface micropuntated. Eyes protruding laterally (Figs. 1-3). Antennae filiform with 11 antennomeres, with few short and thin setae on apex of each antennomere. Clypeus elongate and convex, surface alutaceous without punctures or setae. Frontoclypeal suture straight. Labrum (Fig. 4) subrectangular, anterior margin rounded and slightly prominent at middle; surface with long and thin setae restrict to latero-posterior region (represented by punctures); disc without setae or punctures; antero-lateral margin with long curly setae; antero-posterior margin arcuate. Mandible (Figs. 7-8) asymmetrical, subtriangular, with an articulated sclerotized process on inner subapical edge, with apex rounded in left and tapered in right mandible; lateral lobe more pronounced in dorsal view (Figs. 7A-B); prostheca membranous forming a long lobe below articulated sclerotized process, with long setae on apex and short dense setae on the lateral margin; ventrally, mandible with a latero ventral stout seta; molar region with several transversal carinae (Figs. 8A-B). Maxilla (Fig. 5): cardo elongate, margins sinuous, with one stout seta; stipes large and divided; palpi with four palpomeres; a sensorial pore on each palpomere; distal palpomere elongate, with one seta near middle and several sensilla at apex; galea elongate with one seta near middle and four wide short setae on apex; lacinia subrectangular, $2 \times$ as long as wide, and with a marginal fringe of long setae. Labium (Fig. 6): palpi with three palpomeres, without setae or pore; palpomeres 1-2 transverse; apical palpomere of approximately the length of the basal two combined; ligula wider than long, anterior margin prominent on middle, antero-lateral angles rounded. Epipharynx membranous, anterior margin concave, with a row of robust setae, and with latero-dorsal angles with three short spines. Gena densely covered by tomentum.

Thorax: Pronotum approximately as long as wide (Figs. 1, 3, 9); anterior margin moderately arcuate; an- 


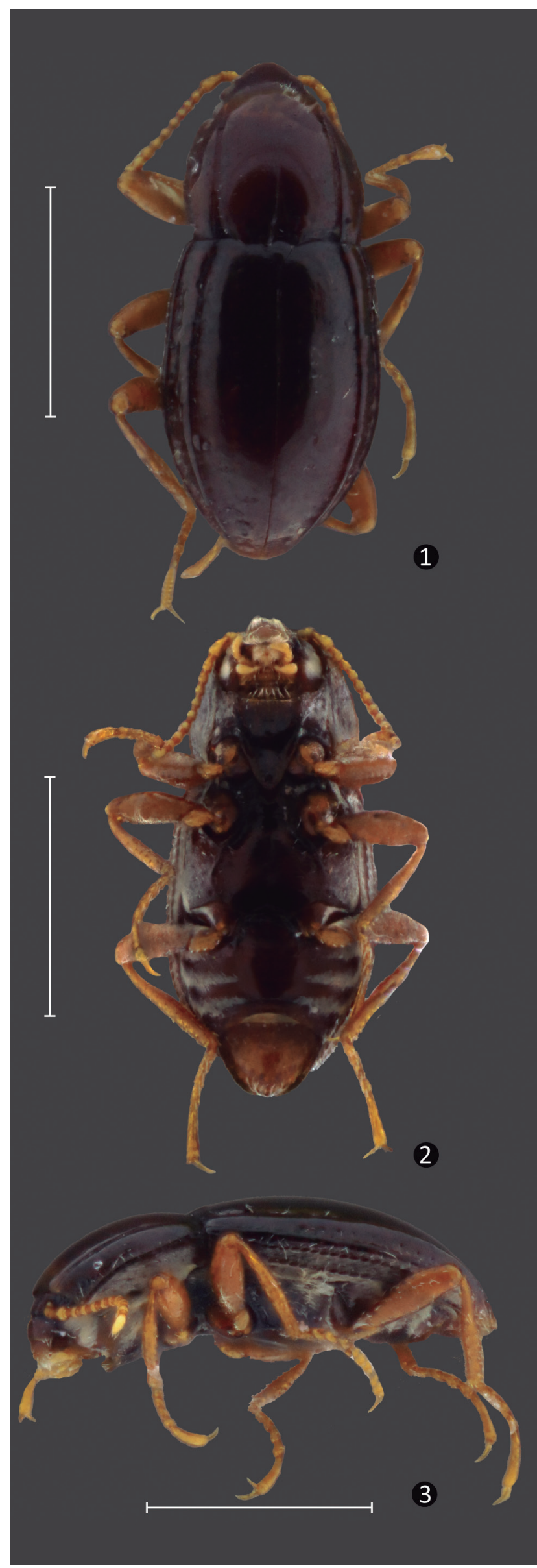

Figures 1-3. Austrolimnius cleidecostae sp. nov. Habitus of holotype (Male). (1) Dorsal view; (2) Ventral view; (3) Lateral view. Scale bars: $0.5 \mathrm{~mm}$. terior angles slightly protruding; lateral margins moderately sinuous; posterior angles acute; posterior margin emarginated, strongly on middle, and smooth near the posterior angles. Pronotum surface alutaceous, glabrous, with inconspicuous micropunctures (Fig. 9); sublateral carinae complete, sinuous, reaching anterior and posterior margins (Figs. 1, 9); longitudinal median impression on posterior $2 / 3$ (Figs. 1, 9). Elytra (Figs. 1, 3)
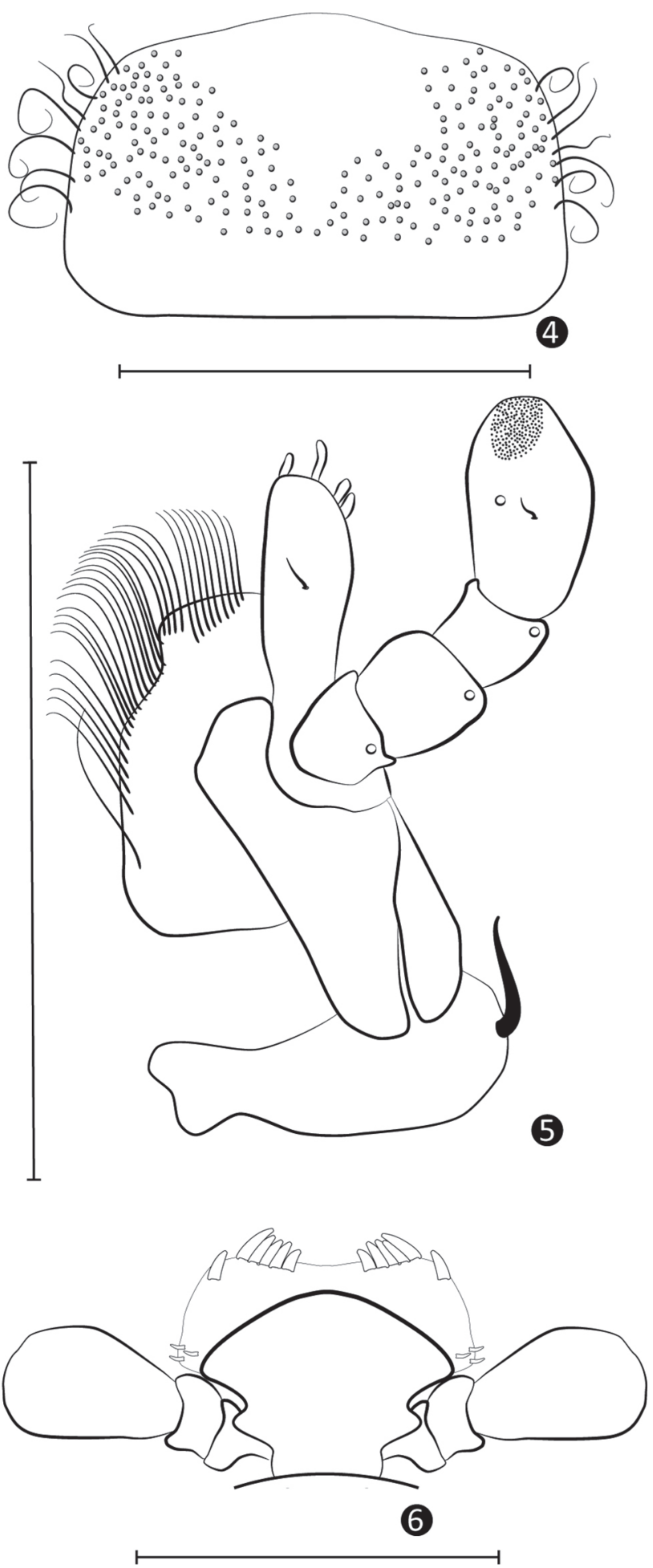

Figures 4-6. Austrolimnius cleidecostae sp. nov., mouthparts, dorsal view. (4) Labrum (setae are represented by punctures); (5) Right maxilla; (6) Labium. Scale bars: $0.1 \mathrm{~mm}$. 
$1.5 \times$ longer than wide; anterior margin arcuate; lateral margins slightly arcuate; apex rounded; median suture slightly elevated; a pair of sublateral carinae extending to apex; surface alutaceous with inconspicuous rows of punctures; lateral margin with row of long and thin setae (Fig. 3). Scutellum oval. Epipleura covered with tomentum with two rows of granules (Fig. 3). Hind wings absent. Prosternum broad, as long as wide, with lateral portion covered by tomentum; disc alutaceous (Fig. 2); prosternal process wide, V-shaped, surpassing procoxae, with a carina on disc, and towards the anterior margin of prosternum (Fig. 2). Hypomerum $3 \times$ as long as wide, covered by tomentum. Mesoventrite as long as wide, with a weak cavity to receive prosternal process. Metaventrite as long as wide, covered laterally by tomentum; disc alutaceous with a complete longitudinal line and a lateral carina; surface with inconspicuous punctures. Legs covered with tomentum, except tibiae and tarsi. Coxae rounded. Trochanter as long as wide, with a row of short and stout setae (Fig. 2). Femora robust, $3 \times$ longer than wide; pro and mesofemur with a dense row of setae on lateral margin. Tibiae narrow, $6 \times$ longer than wide, with a complete row of spines on protibia; meso and metatibiae with two rows of spines reaching $2 / 3$ of the length, and with a row of golden setae between the row of spines. Tarsus elongated; apical tarsomere as long as four pre-
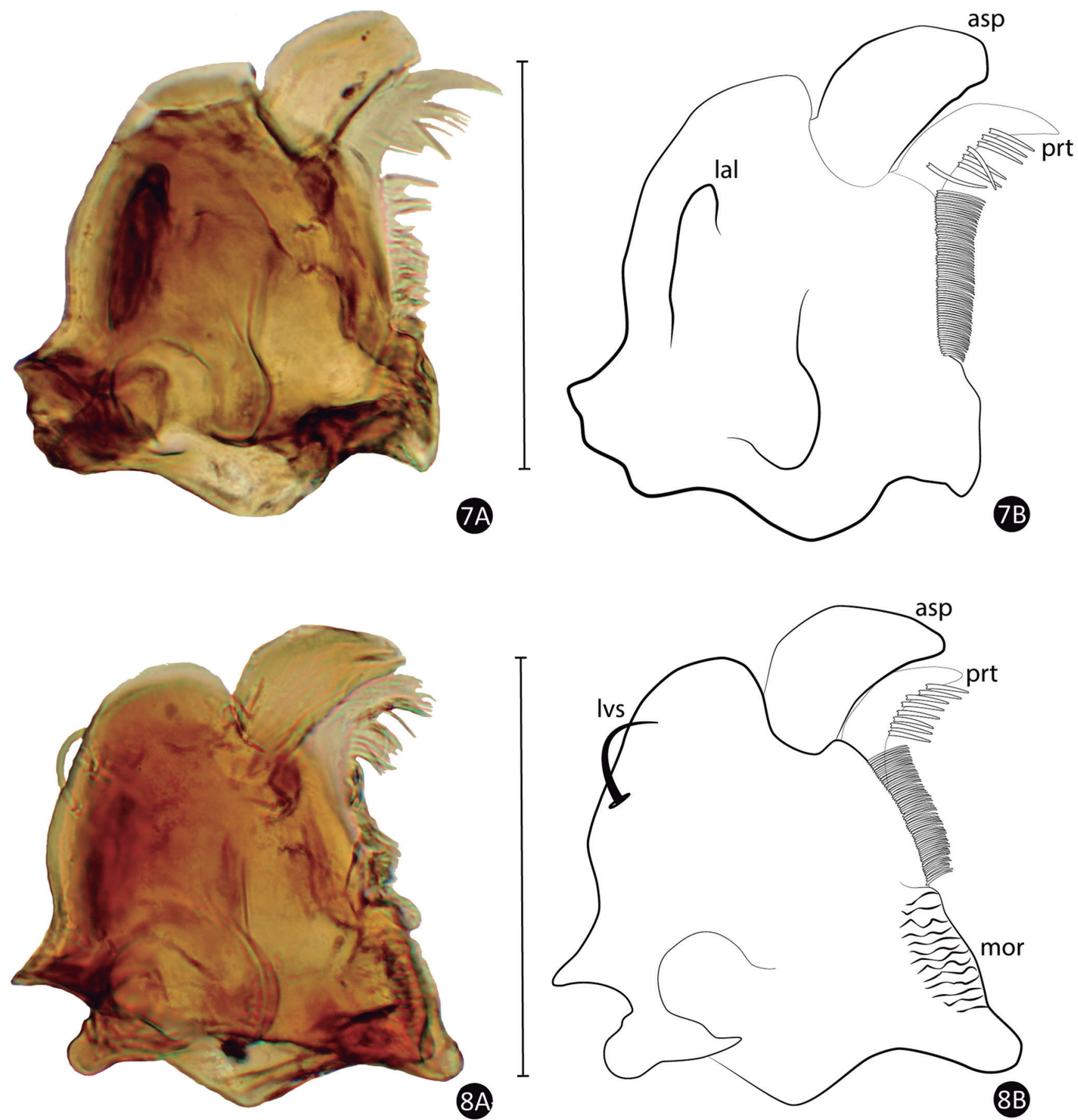

Figures 7-8. Austrolimnius cleidecostae sp. nov. (7-8) Mandibles. (7A, B) Dorsal view of left mandible; (8A, B) Ventral view of right mandible. asp = articulated sclerotized process; lal = lateral lobe; lvs = lateral ventral seta; $p r t=$ prostheca; mor = molar region. Scale bars: $0.1 \mathrm{~mm}$. 
ceding combined; pro- and metatarsi with a pair of stout and short setae on each tarsomere; mesotarsus with a pair of long and thin setae on each tarsomeres. Claws large and stout.

Abdomen: Five ventrites (Figs. 2-3, 10) with margins moderately arcuate; discal surface alutaceous and covered laterally by tomentum. First ventrite with a pair of longitudinal median carinae, extending from anterior to posterior margins, without tomentum. Fifth ventrite with a shallow transverse depression on anterior third; one pair of spiracles antero-laterally; apex slightly sharpened with few setae dorso-laterally and punctures on apex (Fig. 10). Tergite VIII (Fig. 11) almost as long as wide, posterior margin prominent and widely rounded; surface with inconspicuous punctures, apex with a row of short setae. Sternite VIII (Fig. 13) triangular; anterior margin emarginated concave, posterior margin moderately sharp; surface with setae on disc and antero-laterally; apex with a row of punctures; integument with short scale-like setae. Spicule subrectangular and bifurcated at the apical third; apical margin with punctures (Fig. 18).
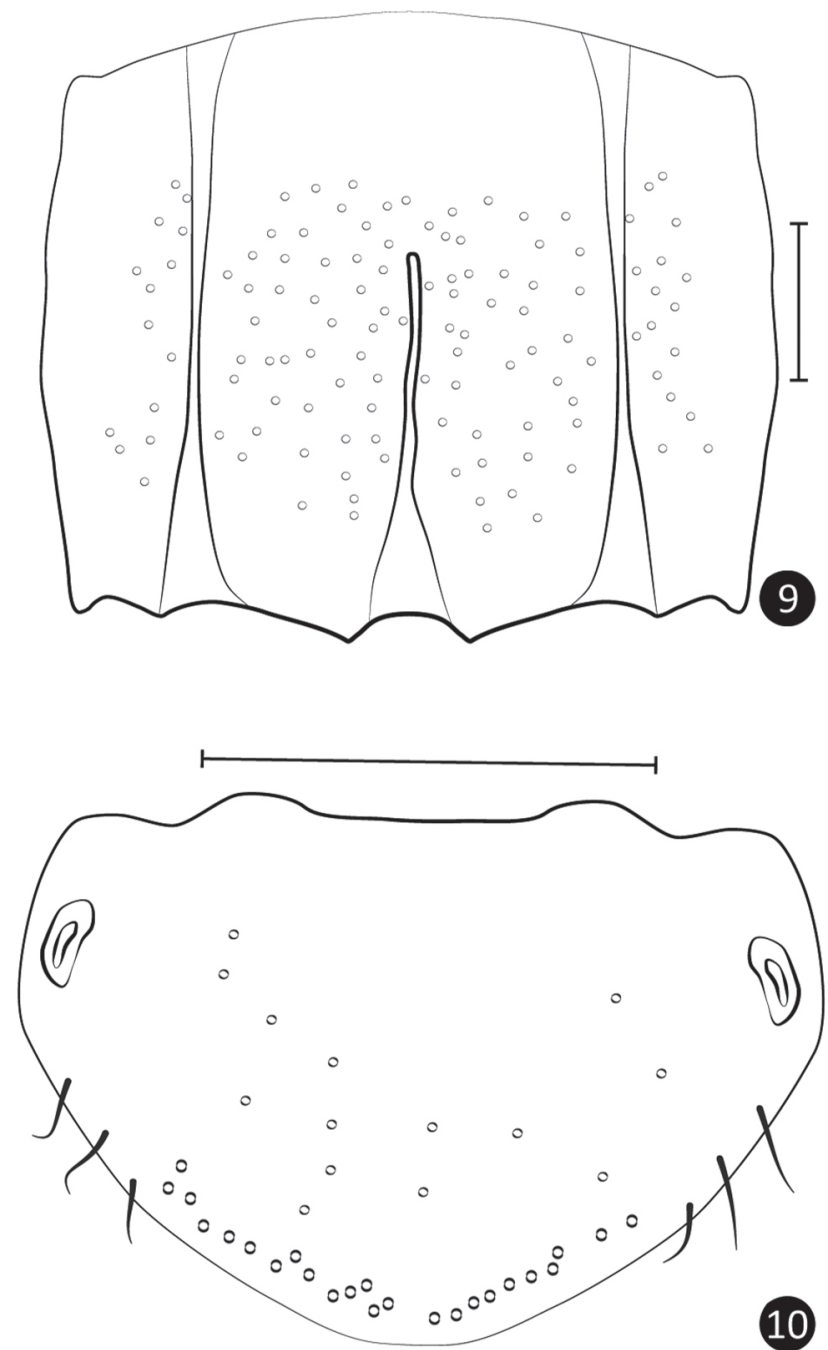

Figures 9-10. Austrolimnius cleidecostae sp. nov. (9) Pronotum; (10) Ventral view of ventrite $V$. Scale bars: $0.1 \mathrm{~mm}$.
Aedeagus: (Figs. 16-17). Phallobase approximately $3 \times$ as long as wide; in lateral view (Fig. 16), wider at apex. Parameres reaching $4 / 5$ of penis length, slightly narrowed to apex, surface with punctures; apex rounded with fringe of long setae and rows of micro punctures (Figs. 16-17). Penis approximately as long as phallobase, $4 \times$ as long as wide; slightly narrowed at apex with sensorial pores; in lateral view (Fig. 16), dorsal margin sclerotized, ventral margin membranous; basolateral apophyses with two lobes; fibula absent; corona present, subquadrate (Fig. 17).

Female: External morphology similar to male, except the pattern of setae on mesotarsus. All tarsi have a pair of stout and short setae on each tarsomere. The golden row of setae between the row of spines in the meso and metatibiae are absent. Tergite VIII has the basal margin emarginated, and apex arcuate; surface with punctures and tuft of long setae on apex (Fig. 12). Sternite VIII elongate; basal margin widely rounded and prominent at middle; apex with setae and punctures; surface with short setae on the disc and antero-laterally; basal projection $3 \times$ longer than sternite, curved (Fig. 14); integument similar to that of the male (Fig. 15).

Female genitalia (Fig. 19): Ovipositor symmetrical. Valvifer membranous, moderately smaller than coxites; curved and convergent on base; wider at apex than at base; apex with punctures; baculus sclerotized. Coxites wider at base than apex, narrowed at the apex, divided by a transverse line; surface with micropunctures, without setae. Styli slightly curved and divergent; apical portion rounded and covered with micropunctures.

Etymology: the specific epithet cleidecostae is a tribute to Dr. Cleide Costa in honour of her many contributions to the study of Coleoptera.

Type locality: São Miguel Arcanjo, São Paulo state, Brazil.

Distribution: São Paulo and Santa Catarina states, Brazil.

\section{Comparative Notes}

Austrolimnius cleidecostae sp. nov. resembles $A$. formosus (Sharp, 1882), A. pusio Hinton, 1941, A. musgravei Hinton, 1939, A. browni Hinton, 1971 and A. eris Hinton, 1971 , in that all species have two rows of granules on the epipleura. However, it can be easily differentiated from $A$. musgravei and $A$. browni by the shape of the body, which is suboval in these species and subparallel in $A$. cleidecostae sp. nov. In addition, $A$. cleidecostae sp. nov. differs from $A$. eris and $A$. pusio by absence of the longitudinal impression on the pronotum in the later. Austrolimnius formosus is distinguished by its fusiform body, complete longitudinal impression on pronotum, tarsi with short setae, male genitalia with parameres longer than penis and female genitalia with the valvifer $2 \times$ longer than coxites. Austrolimnius cleidecostae 

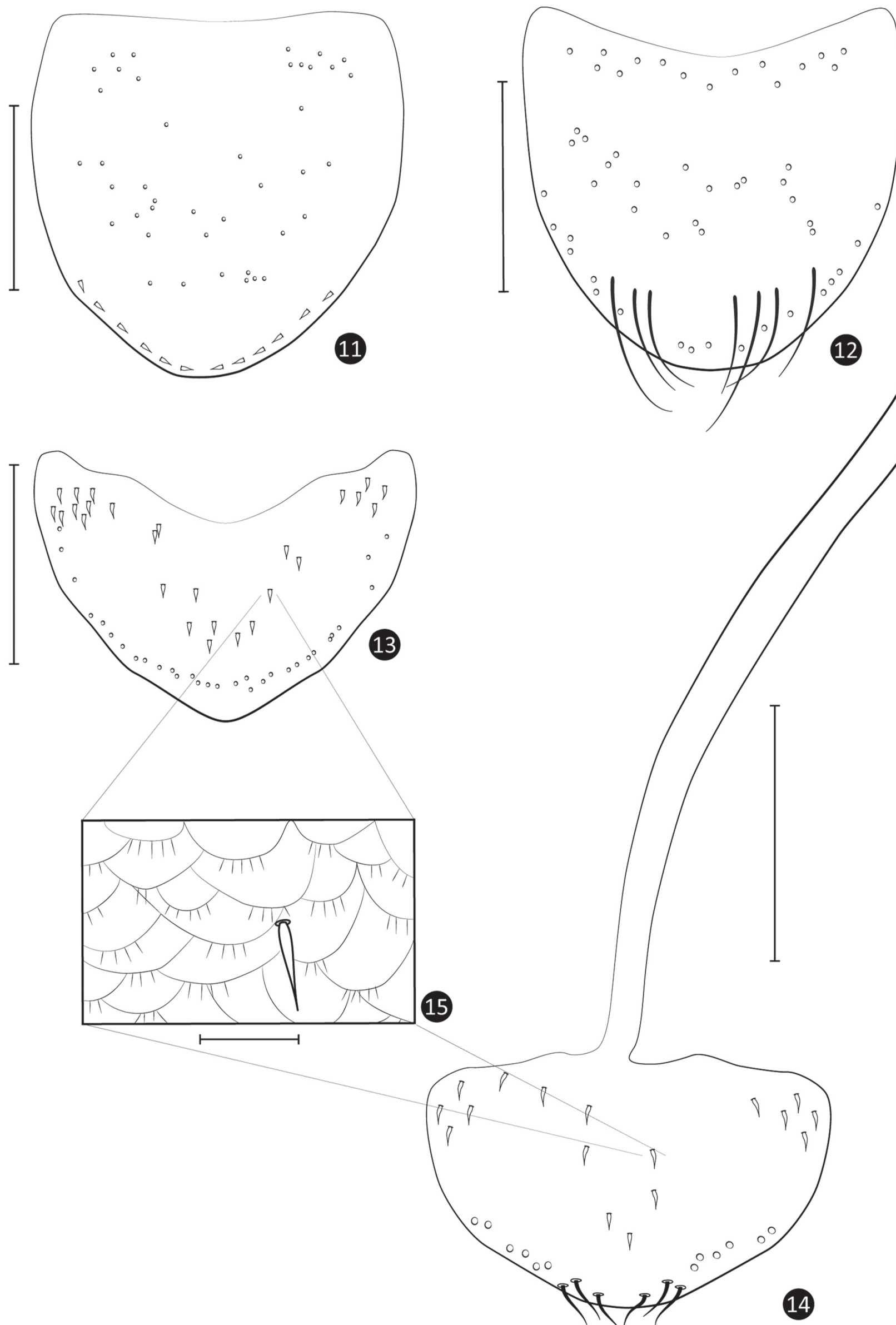

Figures 11-15. Austrolimnius cleidecostae sp. nov. (11) Tergite VIII, male; (12) Tergite VIII, female; (13) Sternite VIII, male; (14) Sternite VIII, female; (15) Scale-like integument (similar in male and female). Scale bars: 11-14: $0.1 \mathrm{~mm}, 15: 0.01 \mathrm{~mm}$. 

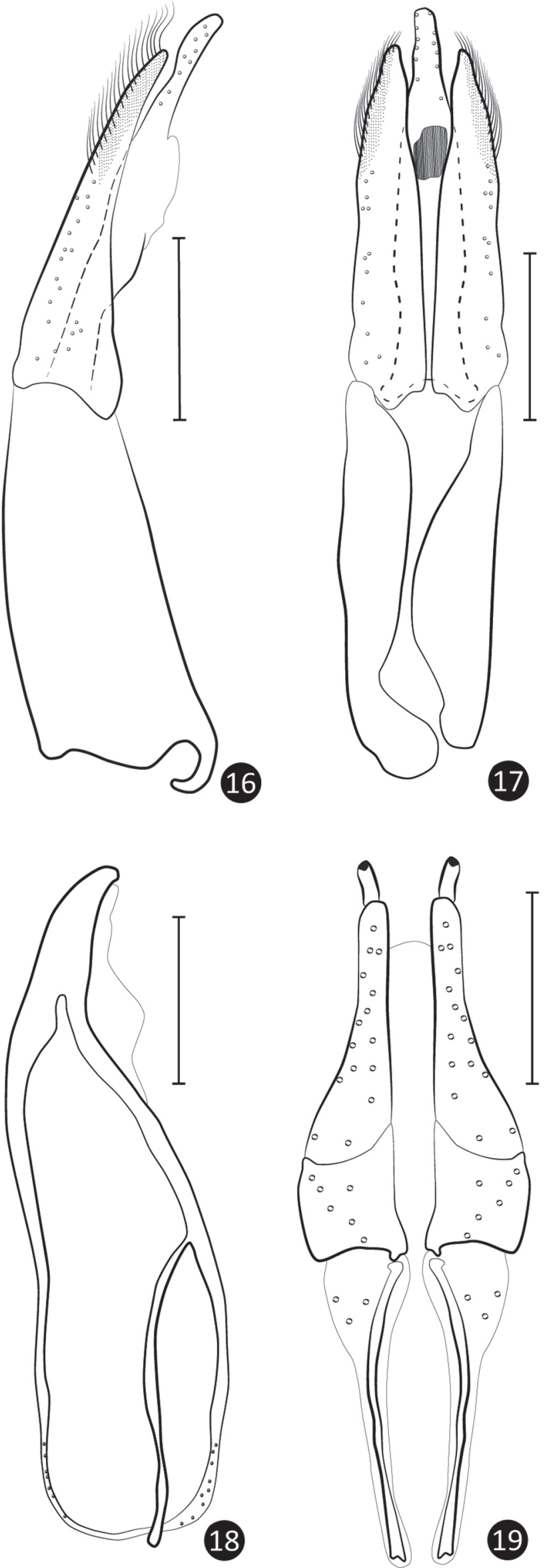

Figures 16-19. Austrolimnius cleidecostae sp. nov. (16-18) Aedeagus: (16) Lateral view; (17) Ventral view; (18) Spicule of male. (19) Female genitalia. Scale bars: $0.1 \mathrm{~mm}$. sp. nov. has a subparallel body, a longitudinal median impression on the pronotum restricted to posterior $2 / 3$, mesotarsus with a pair of long and thin setae on each tarsomere, male genitalia with parameres reaching $4 / 5$ of penis length, and female genitalia with the valvifers moderately smaller than coxites.

\section{Habitat Notes}

The specimens of Austrolimnius cleidecostae sp. nov. were collected in Atlantic rainforest mountain streams, which have high concentrations of oxygen and water temperatures ranging from $14.2^{\circ} \mathrm{C}$ to $15.6^{\circ} \mathrm{C}$. These streams are located in two conservation areas in São Paulo state (Fig. 20): Parque Estadual Carlos Botelho, São Miguel Arcanjo Municipality (type locality) (Fig. 21) and Parque Estadual da Serra do Mar, Cunha Municipality (Fig. 22), and two preserved areas of Santa Catarina state (Fig. 20): Rancho Queimado (Riachos das Antas) (Fig. 23) and São Bonifácio (Riacho Dona Bebê) (Fig. 24). These streams are located in basins with well-preserved vegetation and in elevations that range from $470 \mathrm{~m}$ to $988 \mathrm{~m}$. In general, the specimens were collected in riffles at a depth of $0.1 \mathrm{~m}$ to $0.5 \mathrm{~m}$, in streams with different slopes and with alternating pools and riffles (Figs. 21-24). The holotype of Austrolimnius cleidecostae sp. nov. was collected in a stream (Fig. 21) about four metres wide and at a depth of $0.1 \mathrm{~m}$ to $0.3 \mathrm{~m}$. This stream occurs in a low relief area, which fosters the formation of natural pool (the main mesohabitat in this watercourse) and small riffles with many rocks.

\section{New records of Austrolimnius species to Brazil}

\section{A. browni Hinton, 1971}

"BRASIL. Goiás: Alto Paraíso / de Goiás. Parque Nacional Chapada / dos Veadeiros. Córrego Estiva. / 1406'40,3"S 4744'02,2"W 1162 m / 13.III.2013 Equipe GEEA leg. // Austroliminus browni / Hinton, 1971 / Polizei, T.T.S. det. I.2019" (MZSP 31198).

Distribution: Previously this species was recorded only from Venezuela (Trujillo and Mérida states). This is the first record from Brazil (Goiás state).

\section{A. musgravei Hinton, 1939}

“BRASIL. Amazonas. Rio Preto / da Eva. AM 010 Km 113. Ramal / Casa Branca. 11.IV.2008 / Mateus Pepineli et al. leg. / 02 47'24,1"S 59 30'11,6"W 52 m // Austroliminus musgravei / Hinton, 1939 / Polizei, T.T.S. det. VIII.2019" (10', MZSP 31197).

Distribution: Previously this species was recorded only from the type locality (French Guiana: St. Laurent du Maroni). This is the first record from Brazil (Amazonas state). 

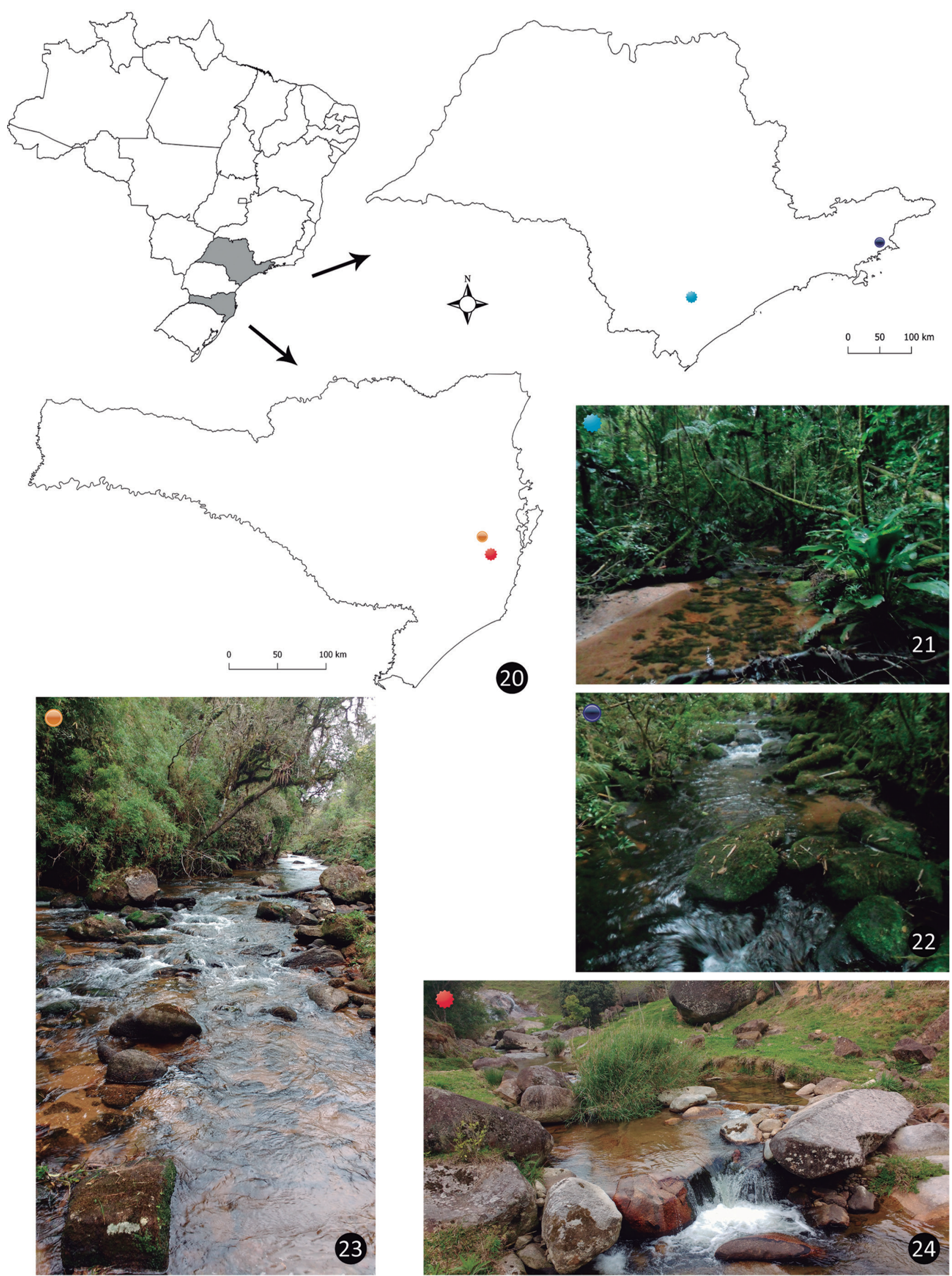

Figures 20-24. Distribution records for Austrolimnius cleidecostae sp. nov. (20) Map of Brazil and São Paulo and Santa Catarina states, showing collection localities of Austrolimnius cleidecostae sp. nov. (21-24) Stream habitats of Austrolimnius cleidecostae sp. nov. (21) São Paulo state, São Miguel Arcanjo, Parque Estadual Carlos Botelho (type locality); (22) São Paulo state, Cunha, Parque Estadual da Serra do Mar; (23) Santa Catarina state, Rancho Queimado, Riacho das Antas; (24) Santa Catarina state, São Bonifácio, Riacho Dona Bebê. 


\section{Distributional records of Austrolimnius in Brazil}

Based on specimens housed in museums and those collected and studied here, we report new records for five species ( $A$. formosus; $A$. eris; $A$. pusio; $A$. bocainensis and $A$. pilulus) for different regions of Brazil (Table 1):

Table 1. Distribution of the species of Austrolimnius to Brazil. Acronyms of Brazilian states: DF $=$ Distrito Federal, $\mathrm{GO}=$ Goiás, MT = Mato Grosso, PA = Pará, $\mathrm{RJ}=$ Rio de Janeiro, $\mathrm{RS}=$ Rio Grande do Sul, $\mathrm{RO}=$ Rondônia, $\mathrm{SC}=$ Santa Catarina, SP = São Paulo. * ${ }^{*}$ represents new records.

\begin{tabular}{|c|c|}
\hline Species & Distribution \\
\hline \multicolumn{2}{|c|}{ A. bocainensis Miranda, Sampaio \& Passos, 2012 Brazil (RJ, SP, SC* , RS*) } \\
\hline A. browni Hinton, 1971 & Venezuela; Brazil* (G0, DF) \\
\hline A. cleidecostae sp. nov. & Brazil (SP, SC) \\
\hline A. eris Hinton, 1971 & $\begin{array}{l}\text { México, Belize, Guatemala, Costa Rica, } \\
\text { Panama, Venezuela, Brazil (G0, DF*), Ecuador; } \\
\text { Argentina }\end{array}$ \\
\hline A. formosus (Sharp, 1882) & $\begin{array}{l}\text { México, Belize, Guatemala, Nicaragua, Costa } \\
\text { Rica, Panama, Venezuela, Brazil (PA*, G0*, } \\
\left.\text { DF* }^{*} \text { MT* }^{*}, \mathrm{RJ}, \mathrm{SP}^{*}, \mathrm{SC}^{*}\right) \text {, Peru, Argentina }\end{array}$ \\
\hline A. laevigatus (Grouvelle, 1889) & Brazil (RJ, SP, SC) \\
\hline A. musgravei Hinton, 1939 & French Guiana, Brazil ${ }^{*}$ (AM) \\
\hline A. pilulus (Grouvelle, 1889) & Brazil (RJ, SP, SC, RS*) \\
\hline A. pusio Hinton, 1941 & Brazil $\left(G 0^{*}, D F^{*}, R 0\right)$, Ecuador \\
\hline A. uncatus Miranda, Sampaio \& Passos, 2012 & Brazil (RJ, SP) \\
\hline
\end{tabular}

\section{Identification key to Austrolimnius species occurring in Brazil (adapted from Miranda et al., 2012)}

1. Epipleura with one row of granules........................................................

1'. Epipleura with two rows of granules....................................................... 2

2. Pronotum with a longitudinal median impression ..................................... 3

2. Pronotum without a longitudinal median impression................................. 6

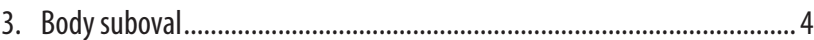

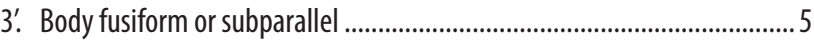

4. Elytra with a short carina near the median suture, and two sublateral carina. A. musgravei Hinton, 1939

4. Elytra with only two sublateral carina ................... A. browni Hinton, 1971

5. Body fusiform. Pronotum with a complete Iongitudinal median impression, reaching the anterior and posterior margins

A. formosus (Sharp, 1882)

5. Body subparallel. Pronotum with an incomplete longitudinal median impression, reaching only the $2 / 3$ posterior portion .

A. cleidecostae sp. nov.

6. Dorsal row of epipleura granules extending to the posterior margin of the mesocoxal cavity; ventral margin of the metatrochanter with tubercles A. eris Hinton, 1971

6'. Dorsal row of epipleura granules extending only to the anterior margin of the procoxal; ventral margin of the metatrochanter without tubercles.. A. pusio Hinton, 1941

7. Mesotarsus without long and conspicuous setae; metatibia cylindrical without expansion and concavity.....

A. bocainensis Miranda, Sampaio \& Passos, 2012

7'. Mesotarsus with long and conspicuous setae; metatibiae with expansion and concavity

8. Metatibiae with expansion on the proximal $2 / 5$, without spines, and with distal concavity A. pilulus (Grouvelle, 1889)

8'. Metatibiae with a medial expansion, with spines on the distal half or spinose concavity in the distal region.
9. Metatibiae without concavity, glabrous antennomeres; aedeagus hooklike; parameres having long setae.

A. uncatus Miranda, Sampaio \& Passos, 2012

9'. Metatibiae with concavity; antennomeres III-VIII with conspicuous setae; aedeagus slightly curved; parameres with short setae.

A. laevigatus (Grouvelle, 1889)

\section{DISCUSSION}

Austrolimnius cleidecostae sp. nov. is one of the smallest species of Elmidae from Neotropical region (total length $1.18-1.20 \mathrm{~mm}$, greatest width $0.45-0.50 \mathrm{~mm}$ ). The new species represents the first record in Elmidae with mandibles having an articulated, sclerotized process on the inner subapical edge. This structure is recorded only in three beetle families: Hydraenidae, Clambidae and Limnichidae (Byrrhinus Motschulsly, 1858) (Lawrence et al., 2011; Leschen, 2016; Jäch et al., 2016b). The function of this mandibular process is unknown. The families with such a structure are phylogenetically unrelated (cf. Lawrence et al., 2011), with distinct habitats and feeding behaviours. Clambidae is included in the superfamily Scirtoidea in the Scirtiformia series and the adults are terrestrial, living in decaying vegetation and feeding on $\mathrm{mi}$ crofungi (Lawrence, 2016). Hydraenidae is in superfamily Staphylinoidea in the Staphyliniformia series. Adults of this family are considered aquatic, with a few species riparian and several genera are terrestrial (humicolous). They feed on algae, spores and detritus. Limnichidae and Elmidae are closely related. Both are included in the superfamily Byrrhoidea, series Elateriformia. Adults of most Limnichidae species (including Byrrhinus) are semiaquatic or riparian, although their feeding behaviour is still unknown. Adults of Austrolimnius cleidecostae sp. nov. are aquatic, living in streams, probably feeding on periphyton or scraping organic matter from rocks, roots, leaves and wood, like most of Elminae.

The new species was collected in streams in São Paulo and Santa Catarina states, in small preserved portions of the Atlantic rainforest. Five species have new records for different regions of Brazil, moreover, here it is recorded for the first time in Brazil the species Austrolimnis browni and A. musgravei. The genus Austrolimnius now comprises 105 species and two subspecies, with 22 species in the Neotropical region, 10 of which recorded to Brazil.

\section{ACKNOWLEDGMENTS}

We thank Neusa Hamada (Instituto Nacional de Pesquisas da Amazônia, Manaus - AM, Brazil), Renan Casimiro (Universidade Católica de Brasília, Brasília - DF, Brazil) for the loan of specimens. We also thank Sônia Casari for the suggestions on this paper. The Coleoptera Curatorial Team in the Natural History Museum, Muséum national d'Histoire naturelle and Museu de Zoologia da Universidade de São Paulo are warmly thanked for their support. We also thank two anonymous reviewers for their suggestions on this paper. TTSP thanks FAPESP (The 
São Paulo Research Foundation, numbers 2015/17064-7 and 2016/21184-0). LSMC and TTSP thank CAPES (Coordination for the Improvement of Higher Education Personnel) for scholarships. PCB thanks FAPESP (numbers 09/53233-7 and 12/21196-8) and CNPq (National Council for Scientific and Technological Development, number 303260/2018-1) for financial support and research fellowship, respectively.

\section{REFERENCES}

Brown, H.P. 1972. Aquatic dryopoid beetles (Coleoptera) of United States. Ohio, U.S. Environmental Protection Agency. 82p. (Biota of Freshwater Ecosystem, Identification Manual, N. 6).

Carter, H.J. \& Zeck, E.H. 1929. A Monograph of the Australian Dryopidae: Order Coleoptera. Australian Zoologist, 6, 49-72 + i-vii.

Grouvelle, A. 1889. Nouvelles espèces d'Helmides. Annales de la Société Entomologique de France, Ser. 6, 8: 393-410, pls. VII-VIII.

Hinton, H.E. 1939. A note on the genus Austrolimnius C. \& Z., with a description of a new species from French Guiana (Coleoptera, Elmidae). Proceedings of the Royal Entomological Society of London, 8(10): 195-199.

Hinton, H.E. 1941. A synopsis of the American species of Austrolimnius Carter (Col., Elmidae). Entomologist's Monthly Magazine, 77: 156-163.

Hinton, H.E. 1965. A revision of the Australian species of Austrolimnius (Coleoptera: Elmidae). Australian Journal of Zoology, 13(1): 97-172.

Hinton, H.E. 1971. Some American Austrolimnius (Coleoptera: Elmidae). Journal of Entomology Series B, Taxonomy, 40(2): 93-99.

Jäch, M.; Ján, K.; Michaela, B.; Shepard, W. \& Fedor, Č. 2016a. Coleoptera: Elmidae and Protelmidae. World Catalogue of Insects, Leiden, Brill. v. 14.
Jäch, M.A.; Beutel, R.G.; Delgado, J.A. \& Díaz, J.A. 2016b. 14.1. Hydraenidae Mulsant, 1844, In: Beutel, R.G. \& Leschen, R.A.B. (Eds.). Coleoptera, Beetles, Volume 1. Morphology and Systematics (Archostemata, Adephaga, Myxophaga, Polyphaga partim). 2.ed. Berlin, Walter de Gruyter. v. 1, p. 316-345. (Handbook of Zoology: Arthropoda: Insecta)

Kodada, J.; Jäch, M.A. \& Fedor, Č. 2016. 19.2. Elmidae Curtis, 1830, In: Beutel, R.G. \& Leschen, R.A.B. (Eds.). Coleoptera, Beetles, Volume 1. Morphology and Systematics (Archostemata, Adephaga, Myxophaga, Polyphaga partim). 2.ed. Berlin, Walter de Gruyter. p. 561-589. (Handbook of Zoology: Arthropoda: Insecta)

Lawrence, J.F. 2016. 2. Classification (families \& subfamilies), In: Beutel, R.G. \& Leschen, R.A.B. (Eds.). Coleoptera, Beetles, Volume 1: Morphology and Systematics (Archostemata, Adephaga, Myxophaga, Polyphaga partim). 2.ed. Berlin, Walter de Gruyter. p. 13-22. (Handbook of Zoology: Arthropoda: Insecta)

Lawrence, J.F.; Ślipiński, A.; Seago, A.E.; Thayer, M.K.; Newton, A.F. \& Marvaldi, A.E. 2011. Phylogeny of the Coleoptera based on morphological characters of adults and larvae. Annales Zoologici, 61(1): 1-217.

Leschen, R.A.B. 2016. 10.3 Clambidae Fischer von Waldheim, 1821. In: Beutel, R.G. \& Leschen, R.A.B. (Eds.). Coleoptera, Beetles, Volume 1: Morphology and Systematics (Archostemata, Adephaga, Myxophaga, Polyphaga partim). 2.ed. Berlin, Walter de Gruyter. p. 211-215. (Handbook of Zoology: Arthropoda: Insecta)

Miranda, G.S.; Sampaio, B.H.L. \& Passos, M.I.S. 2012. Two new species of Austrolimnius Carter \& Zeck (Insecta: Coleoptera: Elmidae) from Southeastern Brazil. Zootaxa, 3389: 14-24.

Sharp, D. 1882. Fam. Parnidae, In: Godman, F.D. \& Salvin, 0. (Eds.). Biologia Centrali-Americana, Insecta, Coleoptera, 1, pt. 2. London, 1882-1887. p. $119-140,1$ pl. 